\title{
Rethinking the
}

\section{Western \\ Tradition}

The volumes in this series

seek to address the present debate

over the Western tradition

by reprinting key works of

that tradition along with essays

that evaluate each text from

different perspectives. 
EDITORIAL

COMMITTEE FOR

\section{Rethinking}

the

\section{Western}

\section{Tradition}

David Bromwich

Yale University

Gerald Graff

University of Illinois at Chicago

Geoffrey Hartman

Yale University

Samuel Lipman

(deceased)

The New Criterion

Gary Saul Morson

Northwestern University

Jaroslav Pelikan

(deceased)

Yale University

Marjorie Perloff

Stanford University

Richard Rorty

Stanford University

Alan Ryan

New College, Oxford

Ian Shapiro

Yale University

Frank M. Turner

Yale University

Allen W. Wood

Stanford University 


\section{The Genteel Tradition in}

American Philosophy

\section{and}

Character and Opinion in the United States

\section{GEORGE SANTAYANA}

Edited and with an Introduction by

James Seaton

with essays by

Wilfred M. McClay

John Lachs

James Seaton

Roger Kimball

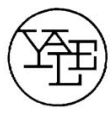

Yale University Press

New Haven and London 
Published with assistance from the Mary Cady Tew Memorial Fund.

Copyright (C) 2009 by Yale University.

All rights reserved.

This book may not be reproduced, in whole or in part, including illustrations, in any form (beyond that copying permitted by Sections 107 and I08 of the U.S. Copyright Law and except by reviewers for the public press), without written permission from the publishers.

Printed in the United States of America.

ISBN: 978-o-300-I I 665-6 (pbk.)

Library of Congress Control Number: 2009930169

A catalogue record for this book is available from the Library of Congress and the British Library.

This paper meets the requirements of ANSI/NISO Z39.48-I992

(Permanence of Paper).

I0 98765432 I 